\title{
Kajian Metode Root Cause Analysis yang Digunakan dalam Manajemen Risiko di Industri Farmasi
}

\author{
Nurike Susendi*, ${ }^{*}$ Adrian $^{1}$, Iyan Sopyan²
}

1Program Studi Profesi Apoteker, Fakultas Farmasi, Universitas Padjadjaran 2Departemen Farmasetika dan Teknologi Farmasi, Fakultas Farmasi, Universitas Padjadjaran,

Jl. Raya Bandung Sumedang Km 21 Jatinangor 45363

*E-mail: nurike16001@mail.unpad.ac.id

(Submit 15/4/2021, Revisi 11/5/2021, Diterima 16/5/2021, Terbit 25/5/2021)

\begin{abstract}
Abstrak
Untuk meningkatkan pengembangan produk, efisiensi proses produksi dan strategi pengendalian, Food and Drug Administration (FDA) mendorong penerapan Quality by Design (QBD) sebagai pendekatan ilmiah yang berbasis pada penerapan mutu risiko dalam pengembangan produk obat. Manajemen risiko bertujuan untuk menganalisis sebuah sistem terhadap potensi penyimpangan yang terjadi untuk mencegah masalah yang lebih serius. Artikel ini bertujuan untuk memberikan pengetahuan mengenai metode root cause analysis yang dapat digunakan dalam manajemen risiko mutu terhadap masalah yang terjadi di industri farmasi. Dalam mereview artikel ini jurnal yang didapat dari berbagai sumber secara daring melalui berbagai jurnal nasional dan internasional yang diakses dari situs Google scholar, Elsevier dan PubMed. Hasil dari review artikel metode analisis akar penyebab, seperti Pareto Analysis, Fishbone Diagram, 5Whys, Failure Mode and Effect Analysis, Brainstorming dan Six Sigma, dapat digunakan untuk menemukan akar penyebab suatu masalah dengan perbedaan masing-masing metode dari segi tahapan, analisis dan penilaian risiko. Dari review yang dibuat, dapat disimpulkan bahwa keenam metode root cause analysis yang diketahui memiliki perbedaan serta kelebihan dan kekurangan masing-masing metode, sehingga dalam penggunaannya dapat disesuaikan dengan kebutuhan suatu masalah yang terjadi di industri farmasi melalui kriteria kelebihan dan kekurangan metode tersebut.
\end{abstract}

Kata kunci: manajemen risiko, industri farmasi, root cause analysis

\section{Pendahuluan}

Untuk meningkatkan pengembangan produk, efisiensi proses produksi dan strategi pengendalian, Food and Drug Administration (FDA) mendorong penerapan Quality by Design (QBD) sebagai pendekatan ilmiah yang berbasis pada penerapan mutu risiko dalam pengembangan produk obat, manufaktur dan regulasi, serta untuk mengidentifikasi karakteristik mutu produk dengan Manajemen risiko mutu ${ }^{1}$. Manajemen risiko bertujuan untuk menganalisis sebuah sistem terhadap potensi penyimpangan yang terjadi untuk mencegah masalah yang lebih serius. 
Manajemen risiko diterapkan pada berbagai aspek industri farmasi. Aspek-aspek tersebut meliputi pengembangan produk, manufaktur, distribusi, inspeksi, penanganan cacat kualitas, bahan obat, eksipien, dan pengemasan produk. Sistem manajemen risiko mutu harus memastikan bahwa setiap evaluasi risiko terhadap kualitas didasarkan terhadap pengetahuan ilmiah, pengalaman dengan prosesnya ${ }^{2}$.

Berdasarkan sistem manajemen mutu ISO 9001:2015, penerapan manajemen risiko diharuskan untuk mempertimbangkan dengan melakukan penilaian risiko ${ }^{3}$. Proses manajemen risiko mutu mengacu pada diagram $\mathrm{ICH}$ Q9 yaitu, penilaian risiko kualitas, pengendalian risiko mutu, komunikasi risiko dan tinjauan risiko ${ }^{4}$. Sebelum dilakukannya penilaian risiko dilakukan identifikasi risiko terlebih dahulu. Pada tahap tersebut dilakukan identifikasi masalah serta memberikan penilaian dalam identifikasi jenis dan faktor risiko dengan mengacu pada data historis dan analisis teori ${ }^{2}$. Untuk melakukan tahapan manajemen risiko mutu diperlukan metode yang digunakan dalam analisis suatu masalah ${ }^{5}$. Beberapa metode yang sering diterapkan untuk penilaian risiko mutu yaitu gabungan metode Failure Mode Effects Analysis (FMEA) dan Fishbone Diagram ${ }^{6}$. Tetapi ada juga beberapa metode yang dapat digunakan untuk penilaian risiko diantaranya yaitu Fishb one Diagram, 5 Whys, Pareto Analysis ${ }^{7,1}$. Tujuan dari review artikel ini yaitu untuk untuk memberikan pengetahuan mengenai metode root cause analysis yang dapat digunakan dalam manajemen risiko mutu terhadap masalah yang terjadi di industri farmasi.

\section{Metode}

Metode yang digunakan dalam penyusunan review artikel ini dengan meninjau literatur secara daring berupa jurnal nasional dan internasional melalui situs Google scholar, Elsevier dan PubMed. Kata kunci yang digunakan dalam penelusuran literatur yaitu "Manajemen Risiko" "Risk Management", "Pareto Analysis", "Fishbone Diagram", "5Whys", "Brainstorming", "Failure Mode And Effect Analysis" dan "Six Sigma". Artikel yang digunakan sebagai referensi berada pada rentang tahun 2009 sampai 2020. Terdapat 37 artikel yang digunakan sebagai referensi penulisan, dengan 7 artikel mengenai manajemen risiko, 5 artikel mengenai Fishbone Diagram, 5 artikel mengenai Pareto Analysis, 4 artikel mengenai 5Whys, 4 artikel mengenai Brainstorming, 6 artikel mengenai Failure Mode Effect Analysis dan 6 artikel mengenai Six Sigma.

\section{Hasil dan Pembahasan}

Metode root cause analysis yang akan dibahas dalam review artikel ini adalah Fishbone Diagram, Pareto Analysis, 5Whys, Brainstorming, Failure Mode Effect Analysis (FMEA) dan Six Sigma. Berikut tahapan, kelebihan dan kekurangan masing-masing metode tersebut. 
Tabel 1. Metode Analisis Risiko Mutu

\begin{tabular}{|c|c|c|}
\hline Metode & Kelebihan & Kekurangan \\
\hline $\begin{array}{l}\text { Fishbone } \\
\text { Diagram }\end{array}$ & $\begin{array}{lrr}\text { Mengidentifikasi } & \text { kategori Dapat } & \text { memberikan } \\
\text { penyebab menggunakan 4M kerangka teoritis yang } \\
\text { dan 1E yaitu Man (manusia) komprehensif untuk } \\
\text { personalia yang berkaitan, mewakili } & \text { dan } \\
\text { Methods (metode) prosedur menganalisis } & \text { akar } \\
\text { atau metode yang digunakan, penyebab } & \\
\text { Machine (mesin) peralatan } & \\
\text { yang digunakan, Materials } \\
\text { (bahan) bahan yang digunakan } \\
\text { dan Environment (lingkungan) } \\
\text { kondisi yang terjadi pada } \\
\text { proses berlangsung }{ }^{10} \text {. }\end{array}$ & $\begin{array}{l}\text { Tidak dapat } \\
\text { memfasilitasi korelasi } \\
\text { analisa antar akar } \\
\text { penyebab yang } \\
\text { potensial dari masing- } \\
\text { masing kategori yaitu } \\
4 \mathrm{M} \text { dan 1E, selain itu } \\
\text { penyajian data yang } \\
\text { digunakan hanya } \\
\text { kualitatif }^{33} \text {. }\end{array}$ \\
\hline $\begin{array}{l}\text { Pareto } \\
\text { Analysis }\end{array}$ & 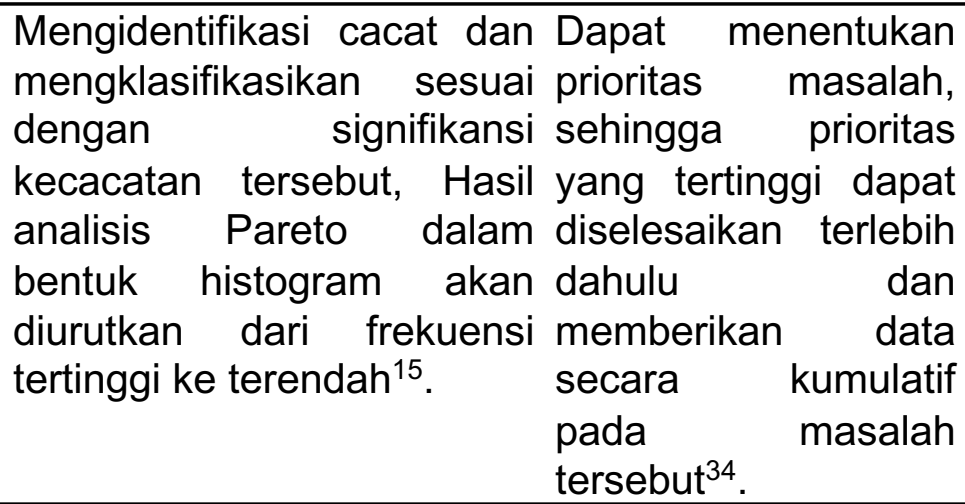 & $\begin{array}{l}\text { Tidak dapat } \\
\text { mengidentifikasi } \\
\text { akar penyebab } \\
\text { suatu masalah, } \\
\text { karena data pareto } \\
\text { yang didapat hanya } \\
\text { kualitatif saja }{ }^{34} \text {. }\end{array}$ \\
\hline 5Whys & $\begin{array}{l}\text { Mengidentifikasi hubungan Metoder } \\
\text { antara akar penyebab yang sederhana sehingga } \\
\text { berbeda dari tiap masalah banyak diterapkan } \\
\text { dengan membentuk dalam penyelesaian } \\
\text { pernyataan dan bertanya masalah }{ }^{18} \text {. } \\
\text { pernyataan } \\
\text { mengapa keadaan itu } \\
\text { terjadi sampai akar } \\
\text { penyebab ditemukan }{ }^{16} \text {. }\end{array}$ & $\begin{array}{lr}\text { Hanya } & \text { dapat } \\
\text { diaplikasikan } & \text { pada } \\
\text { masalah } & \text { yang } \\
\text { sederhana, } & \\
\text { sehingga } & \text { tidak } \\
\text { sesuai } & \text { dengan } \\
\text { masalah } & \text { yang } \\
\text { kompleks } & \\
\end{array}$ \\
\hline Brainstorming & $\begin{array}{l}\text { Metode yang digunakan Dapat memberikan } \\
\text { dalam masalah tertentu kebebasan } \\
\text { dengan mengumpulkan berpendapat dan } \\
\text { semua ide secara spontan setiap ide dianggap } \\
\text { dari tiap anggota suatu sebagai solusi untuk } \\
\text { kelompok, sehingga suatu masalah }{ }^{19} \text {. } \\
\text { mendapatkan banyak ide }{ }^{19} \text {. }\end{array}$ & $\begin{array}{l}\text { Proses diskusi yang } \\
\text { membutuhkan } \\
\text { banyak waktu dan } \\
\text { tenaga }^{19} \text {. }\end{array}$ \\
\hline
\end{tabular}




\begin{tabular}{|c|c|c|c|}
\hline $\begin{array}{l}\text { Failure Mode } \\
\text { Effect Analysis }\end{array}$ & $\begin{array}{l}\text { Menggunakan } \\
\text { probabilitas, deteksi dan } \\
\text { tingkat keparahan kriteria } \\
\text { untuk mengembangkan } \\
\text { Risk Priority Number } \\
\text { (RPN) yang digunakan } \\
\text { dalam menentukan } \\
\text { peringkat pertimbangan } \\
\text { korektif }{ }^{3} \text {. }\end{array}$ & $\begin{array}{l}\text { Dapat memberikan } \\
\text { definisi, identifikasi } \\
\text { dan penilaian suatu } \\
\text { masalah, sehingga } \\
\text { dapat membantu } \\
\text { dalam pengambilan } \\
\text { keputusan } \\
\text { berdasarkan RPN }{ }^{36} \text {. }\end{array}$ & $\begin{array}{l}\text { Kombinasi } \\
\text { berbeda dari } \\
\text { parameter } \\
\text { menghasilkan } \\
\text { yang } \\
\text { sehingga sulit } \\
\text { menilai pasti } \\
\text { faktor risiko }\end{array}$ \\
\hline Six Sigma & $\begin{array}{l}\text { Menggunakan model yang } \\
\text { dikenal sebagai DMAIC } \\
\text { (Define, Measure, } \\
\text { Analyze, Improve dan } \\
\text { Control) }{ }^{29} \text {. }\end{array}$ & $\begin{array}{l}\text { Metode yang } \\
\text { berbasis data statistik } \\
\text { dan prospektif, lebih } \\
\text { fokus kepada } \\
\text { mencegah daripada } \\
\text { memperbaiki suatu } \\
\text { masalah }{ }^{37} \text {. }\end{array}$ & $\begin{array}{l}\text { Memerlukan } \\
\text { komitmen } \\
\text { panjang } \\
\text { berkelanjutan, } \\
\text { rumit dalam a } \\
\text { data statistik }{ }^{37}\end{array}$ \\
\hline
\end{tabular}

\section{Fishbone Diagram}

Fishbone Diagram atau Diagram Ishikawa adalah suatu teknik root cause analysis yang menunjukkan beberapa penyebab dari suatu peristiwa atau kejadian tertentu. Secara khusus, Fishbone Diagram berbentuk seperti kerangka ikan, diagram ini umum digunakan untuk analisis sebab dan akibat untuk mengidentifikasi interaksi penyebab yang kompleks suatu masalah atau peristiwa tertentu. Fishbone diagram dapat menjadi kerangka teoritis yang komprehensif untuk mewakili dan menganalisis akar penyebab ${ }^{8}$. Fishbone Diagram juga dapat menguraikan setiap masalah yang diidentifikasi dan semua orang yang terlibat dapat memberikan saran yang mungkin menjadi penyebab masalah ${ }^{9}$. Prosedur yang digunakan untuk menganalisis akar masalah menggunakan Fishbone Diagram dalam identifikasi penyebab masalah yaitu: menyiapkan diagram Fishbone Analysis, mengidentifikasi efek atau masalah, mengidentifikasi kategori penyebab utama, menemukan penyebab potensial dengan meminta saran, meninjau setiap kategori penyebab utama, menemukan konsensus untuk kemungkinan penyebab, dan menerapkan hasil analisis ${ }^{9}$. Berikut merupakan gambaran dari Fishbone Diagram

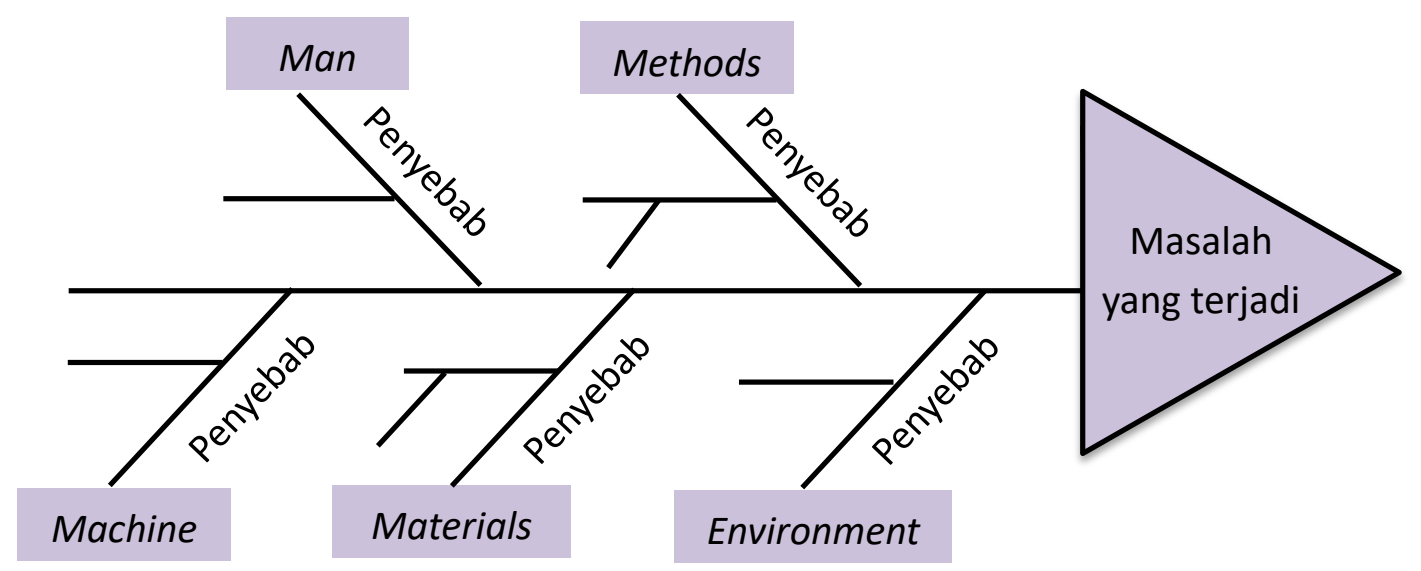

Gambar 1. Fishbone Diagram ${ }^{11}$ 
Pada umumnya mengidentifikasi kategori penyebab utama menggunakan kategori 4M dan 1E yaitu Man (manusia) personalia yang berkaitan dan bertanggung jawab, Methods (metode) prosedur atau metode yang digunakan, Machine (mesin) peralatan atau sistem penunjang yang digunakan, Materials (bahan) bahan baku dan bahan tambahan yang digunakan dan Environment (lingkungan) keadaan kondisi yang terjadi pada proses berlangsung ${ }^{10}$.

2. Pareto Analysis

Analisis pareto membantu untuk mengidentifikasi cacat yang berbeda dan mengklasifikasikannya sesuai dengan signifikansi kecacatan tersebut. Kemudian analisis masalah tersebut mengurutkan semua cacat yang berbeda dengan signifikansi relatifnya terhadap penolakan total ${ }^{12}$. Diagram pareto sangat berguna dalam menentukan target untuk menentukan masalah yang paling penting untuk ditangani terlebih dahulu ${ }^{13}$. Berikut tahapan untuk melakukan analisis pareto:

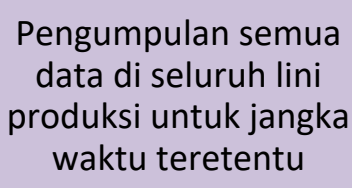

Pengumpulan semua data di seluruh lini produksi untuk jangka waktu teretentu
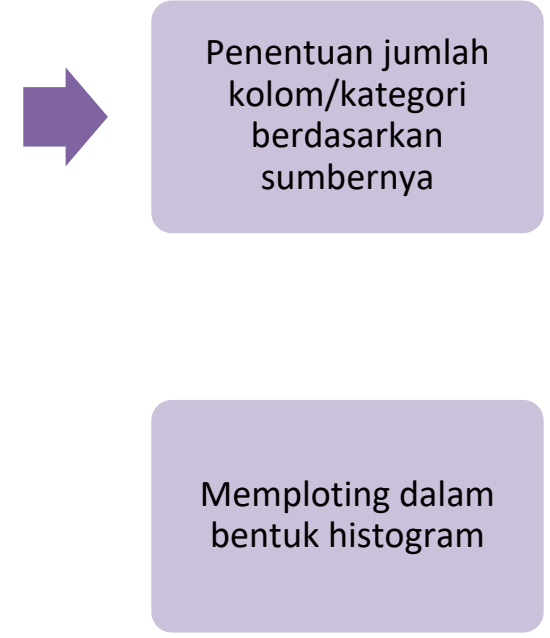

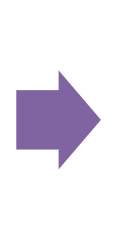

Mengatur kategori dalam urutan menurun menurut kontribusi individu

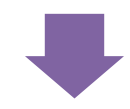

Mentabulasi kontribusi individu dalam persen dari total dan kumulatif

Gambar 2. Tahapan Analisis Pareto ${ }^{14}$

Hasil analisis Pareto dalam bentuk histogram akan diurutkan dari frekuensi tertinggi ke frekuensi terendah untuk mengidentifikasi bagian mana penyimpangan yang langsung mempengaruhi masalah dan bagian mana yang tidak mempengaruhi ${ }^{15}$.

\section{5 Whys}

Analisis 5-Whys digunakan untuk menyelidiki akar penyebab dari sebuah masalah atau penyimpangan yang terjadi pada suatu produksi. Prinsip dasar dari analisis 5Whys adalah untuk membentuk pernyataan situasi dan bertanya mengapa kejadian itu terjadi, kemudian mengubah jawaban dari jawaban pertama menjadi pertanyaan untuk kedua. Proses serupa diulangi sampai akar penyebab yang mendasari kejadian tersebut terungkap ${ }^{16}$. 
Tujuan pengulangan dari pertanyaan tersebut adalah untuk mengeksplorasi hubungan sebab akibat yang mendasari adanya masalah serius yang terjadi. Analisis 5-Whys membantu mengidentifikasi akar penyebab dari masalah, dan menentukan hubungan antara akar penyebab yang berbeda dari tiap masalah ${ }^{17}$. Berikut contoh masalah yang diselesaikan dengan metode 5-Whys:

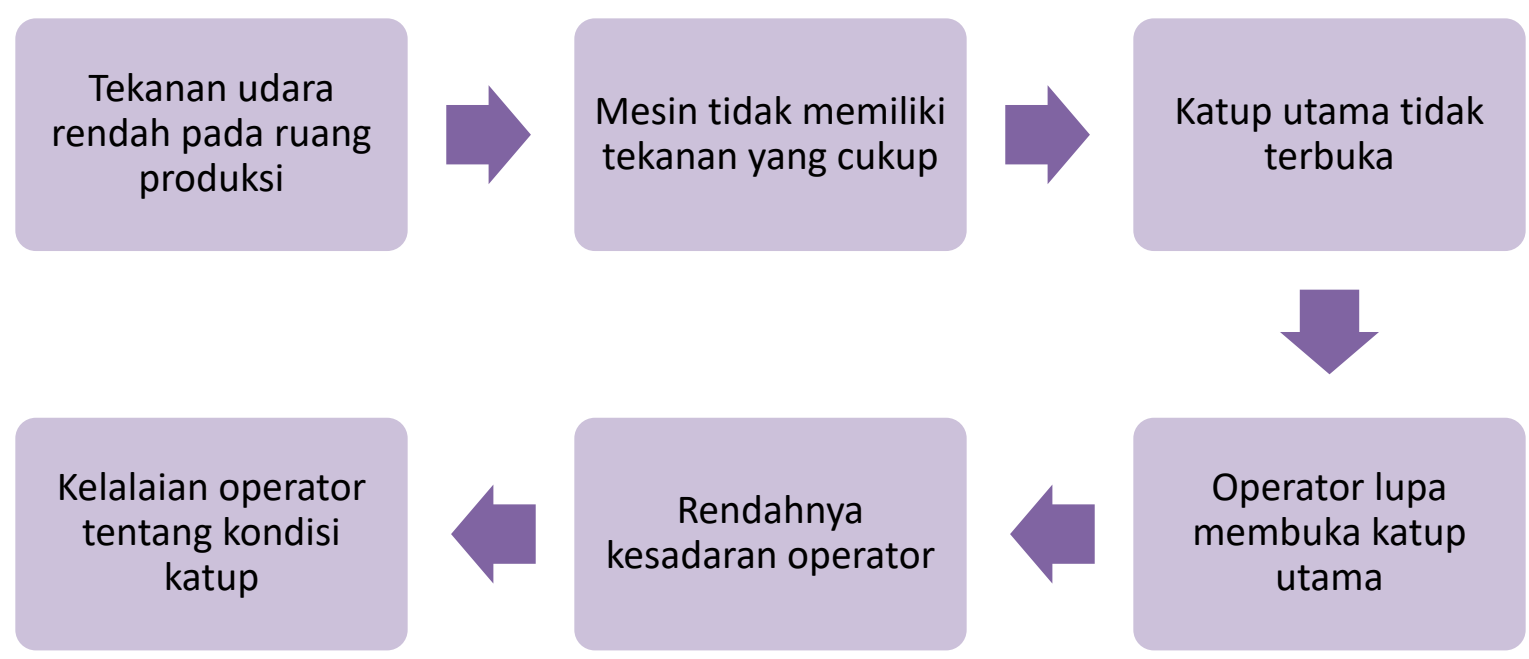

Gambar 3. Tahapan Analisis 5-Whys ${ }^{16}$

Kesederhanaan analisis yang tampak dari 5-Whys ini menjadikannya banyak diterapkan dalam penyelesaian masalah, tetapi kesederhanaan metode 5-Whys menyembunyikan kerumitan dalam metodologi dan tanpa disadari dapat menyebabkan kesalahan dalam penerapannya, sehingga mengakibatkan masalah yang diperbaiki merupakan masalah yang tidak menyebabkan insiden kegagalan dan melewatkan masalah yang menyebabkannya ${ }^{18}$.

\section{Brainstorming}

Brainstorming adalah metode untuk memaksimalkan kreativitas kelompok dalam pemecahan masalah. Brainstorming merupakan adalah teknik dimana suatu kelompok mencoba menemukan solusi untuk masalah tertentu dengan mengumpulkan semua ide secara spontan dari anggotanya ${ }^{19}$. Brainstorming membantu kelompok menghasilkan banyak ide tanpa penilaian dalam waktu singkat. Setiap anggota kelompok belajar menawarkan ide. Siklus ini berulang sampai semua ide habis ${ }^{20}$.

Dalam metode brainstorming, tim diajak untuk mengajukan ide apa pun mengenai permasalahan yang dihadapi. Setiap ide dianalisis, disintesis dan dievaluasi. Tim tidak diminta untuk menilai ide selama proses brainstorming berlangsung. Penilaian terhadap ide akan dilakukan pada periode berikutnya dimana semua ide dipilih, dievaluasi dan mungkin diterapkan ${ }^{21}$. 
Brainstorming individu cenderung menghasilkan ide-ide yang lebih luas daripada brainstorming kelompok, tetapi cenderung tidak mengembangkan ide-ide secara efektif, terutama ketika individu menghadapi masalah yang tidak dapat mereka pecahkan. Individu bebas untuk mengeksplorasi ide-ide pada waktunya sendiri tanpa rasa takut dikritik, dan tanpa didominasi oleh anggota kelompok lainnya. Sementara brainstorming kelompok mengembangkan ide-ide lebih dalam dan efektif, seperti ketika kesulitan dalam pengembangan ide oleh individu. Brainstorming kelompok cenderung menghasilkan lebih sedikit ide karena waktu yang dihabiskan untuk mengembangkan ide-ide secara mendalam ${ }^{19}$.

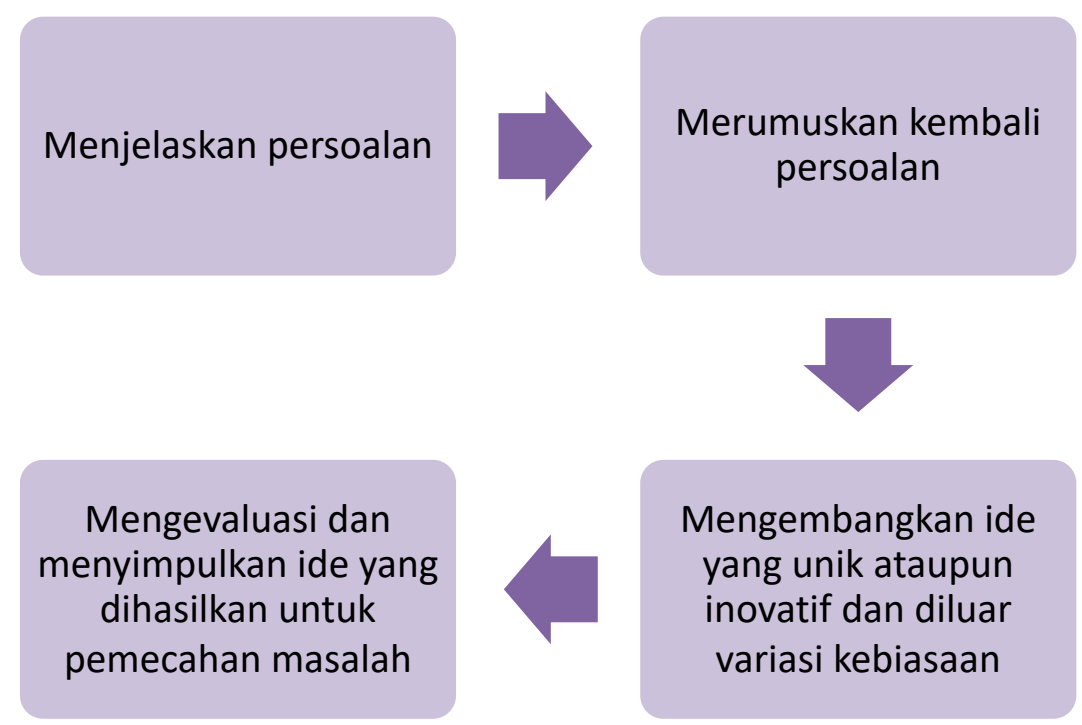

Gambar 4. Tahapan brainstorming 22

\section{Failure Mode Effect Analysis (FMEA)}

Analisis FMEA bertujuan untuk menganalisis karakteristik desain relatif terhadap proses manufaktur yang direncanakan untuk memastikan bahwa produk yang dihasilkan memenuhi kebutuhan dan harapan pelanggan. Ketika mode kegagalan diidentifikasi, kemungkinan terjadinya kegagalan dapat dikurangi dengan mengambil beberapa tindakan yang benar. FMEA menggunakan probabilitas deteksi dan kejadian selain dengan tingkat keparahan kriteria untuk mengembangkan Risk Priority Number (RPN) untuk menentukan peringkat pertimbangan tindakan korektif ${ }^{23}$.

Metode RPN mengharuskan tim analisis untuk melakukan penilaian teknik untuk menilai setiap masalah potensial menurut tiga skala penilaian, yaitu:

1. Keparahan (severity), menilai tingkat keparahan efek potensial dari kegagalan.

2. Kejadian (occurrence), menilai kemungkinan kegagalan akan terjadi.

3. Deteksi (detection), menilai kemungkinan bahwa masalah akan terdeteksi sebelum mencapai pengguna akhir ${ }^{24}$.

Ketiga atribut risiko tersebut dinilai oleh tim lintas fungsional sesuai dengan skala numerik dari 1 hingga 10 untuk setiap mode kegagalan. Peringkat dari setiap atribut dikalikan untuk menghitung RPN25. 
Terdapat beberapa manfaat yang dapat diperoleh pada penggunaan analisis FMEA, diantaranya: keandalan yang lebih tinggi, kualitas yang lebih baik, peningkatan keselamatan dan kontribusinya terhadap penghematan biaya termasuk penurunan waktu pengembangan dan pengurangan limbah. Keuntungan biaya yang terkait dengan FMEA biasanya didapatkan dari kemampuan untuk mengidentifikasi mode kegagalan lebih awal dalam proses. Manfaat finansial juga diperoleh dari perbaikan desain yang diharapkan dapat difasilitasi oleh FMEA, termasuk pengurangan biaya garansi, peningkatan penjualan melalui peningkatan kepuasan pelanggan, dan lainlain $^{24}$.

Di samping itu, terdapat beberapa keterbatasan dalam penggunaan pendekatan FMEA tradisional. Proses FMEA yang berorientasi pada pengambilan keputusan berdasarkan kelompok dapat menyebabkan tingkat hambatan tertentu yang umum dalam proses pengambilan keputusan kelompok. Dalam banyak skenario evaluasi risiko yang realistis, tim FMEA dapat terdiri dari anggota dari berbagai bagian dengan keahlian dan keterampilan yang berbeda-beda. Oleh karena itu, penilaian mereka umumnya dapat menyebabkan ambiguitas dan dalam beberapa kasus mungkin kurang pasti ${ }^{26}$.

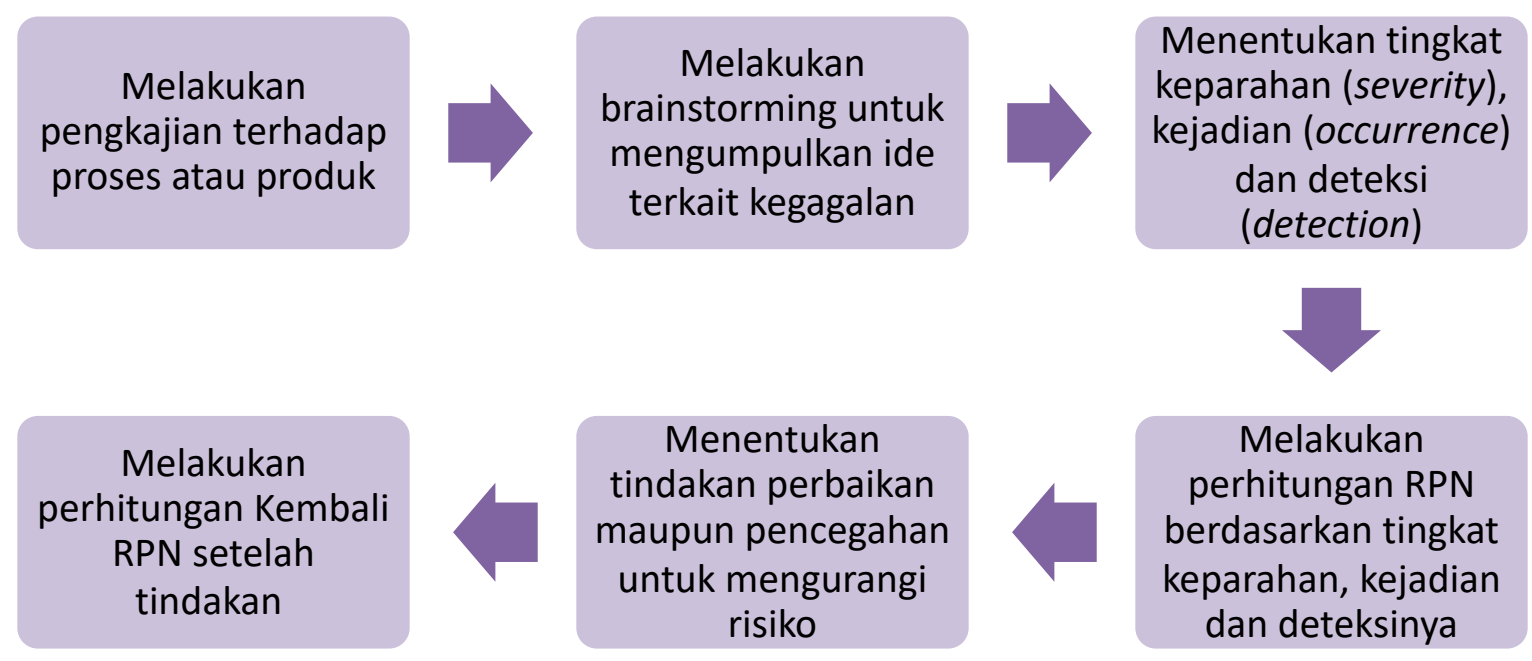

Gambar 5. Tahapan Failure Mode Effect Analysis (FMEA) ${ }^{27}$

\section{Six sigma}

Six sigma merupakan metodologi berbasis data yang digunakan untuk mengidentifikasi akar penyebab variasi dalam proses produksi Strategi manajemen six sigma mengidentifikasi perbaikan terhadap proses melalui identifikasi masalah, akar penyebab, desain ulang proses, rekayasa ulang, dan manajemen proses. Six sigma mengikuti model yang dikenal sebagai DMAIC (Define, Measure, Analyze, Improve dan Control) ${ }^{28}$. 
Model DMAIC terdiri dari29,30:

1. Define: melakukan pengembangan ruang lingkup dan validasi kepentingan, membentuk tim yang dapat bertanggung jawab atas proyek, dan identifikasi kebutuhan utama pelanggan.

2. Measure: menentukan fokus masalah, melakukan pengumpulan data, memeriksa keandalan data, mengidentifikasi prioritas masalah, dan menetapkan tujuan dari masalah.

3. Analyze: menentukan penyebab setiap masalah, menganalisis proses menghasilkan masalah, mengidentifikasi dan memprioritaskan penyebab potensial masalah, dan menghitung pentingnya penyebab potensial.

4. Improve: mengusulkan, mengevaluasi, dan mengimplementasikan solusi untuk setiap masalah; mengidentifikasi solusi untuk masalah; menguji solusi perbaikan dalam skala kecil; mengembangkan dan mengimplementasikan rencana solusi dalam skala besar.

5. Control: memastikan bahwa cakupan tujuan jangka panjang dipertahankan, menilai pencapaian tujuan dalam skala besar, menerapkan rencana pemantauan kinerja dan mengambil tindakan korektif jika terjadi anomali.

Pendekatan six sigma menekankan pada karakteristik kualitas kritis dari produk atau proses. Dengan analisis yang cermat dari karakteristik tersebut, penggunaan six sigma mampu menentukan dan memperbaiki kegagalan dan variabilitas ${ }^{31}$. Di samping itu, metode six sigma digunakan untuk menganalisis dan memperbaiki masalah, namun tidak membahas bagaimana mengoptimalkan aliran proses. Oleh karena itu, biasanya digunakan kombinasi antara six sigma dengan perangkat "lean" untuk menghasilkan peningkatan dan perbaikan yang lebih baik ${ }^{28}$. Fokus Lean adalah untuk meningkatkan aliran proses dan mengurangi pemborosan dan variabilitas, sementara six sigma berkonsentrasi pada peningkatan proses dengan mengidentifikasi masalah, mengumpulkan dan menganalisis data untuk mengidentifikasi dan menghilangkan akar penyebab masalah ${ }^{32}$.

\section{Kesimpulan}

Berdasarkan hasil review jurnal yang didapat, enam metode analisis akar penyebab yang sudah dijelaskan, yaitu: Fishbone diagram, Pareto analysis, 5 Whys, Brainstroming, Failure Mode Effect Analysis (FMEA), dan Six sigma. Keenam metode tersebut dapat digunakan sebagai metode analisis akar penyebab dengan memiliki tahapan, analisis dan penilaian risiko yang berbeda dari suatu masalah, sehingga untuk penggunaannya dapat disesuaikan dengan kebutuhan suatu masalah yang terjadi di industri farmasi melalui kriteria kelebihan dan kekurangan metode tersebut.

\section{Daftar Pustaka}

1. Stocker E, Becker K, Hate S, Hohl R, Schiemenz W, Sacher S, Zimmer A, SalarBehzadi S. Application of ICH Q9 Quality Risk Management Tools for Advanced Development of Hot Melt Coated Multiparticulate Systems. Journal of pharmaceutical sciences. 2017;106(1):278-90. 
2. Vartak RP, Bhagure GR. Quality Risk Management in Pharmaceutical Industry-A Overview. Asian Journal of Chemistry. 2012;24(12):5576.

3. Yuthika R, Widaningrum S, Lalu H. Perancangan SOP Pengendalian Informasi Terdokumentasi Berdasarkan Integrasi ISO 9001: 2015 Klausul 7.5 dan ISO 14001: 2015 Klausul 7.5 Dengan Mempertimbangkan Risiko Menggunakan Metode Business Process Improvement di CV. XYZ. eProceedings of Engineering. 2016;3(2).

4. Engisch W, Muzzio F. Using Residence Time Distributions (RTDs) to Address the Traceability of Raw Materials in Continuous Pharmaceutical Manufacturing. Journal of Pharmaceutical Innovation. 2016;11(1):64-81.

5. Sari DP, Purwanggono B, Umiyatun S. Pemenuhan Kualitas Menggunakan Pendekatan Quality Risk Management (Studi Kasus di PT. Asrindo Indty Raya). Jurnal IImiah Ekonomi Bisnis. 2011;15(2).

6. Charoo NA, Shamsher AA, Zidan AS, Rahman Z. Quality by design approach for formulation development: a case study of dispersible tablets. International journal of pharmaceutics. 2012;423(2):167-78.

7. Ershadi MJ, Aiasi R, Kazemi S. Root cause analysis in quality problem solving of research information systems: a case study. International Journal of Productivity and Quality Management. 2018;24(2):284-99.

8. Coccia M. The Fishbone Diagram to Identify, Systematize and Analyze the Sources of General Purpose Technologies. Journal of Social and Administrative Sciences. 2018;4(4):291-303.

9. Slameto S. The Application of Fishbone Diagram Analisis to Improve School Quality. Dinamika llmu: Jurnal Pendidikan. 2016; 16(1): 59-74.

10. Liliana L. A New Model of Ishikawa Diagram for Quality Assessment. InIOP Conference Series: Materials Science and Engineering 2016 Nov 1 (Vol. 161, No. 1, p. 012099). IOP Publishing.

11. Raman RS, Basavaraj Y. Quality Improvement of Capacitors Through Fishbone and Pareto Techniques. International Journal of Recent Technology and Engineering. 2019;8(2):2248-52.

12. Ahmed M, Ahmad N. An Application of Pareto Analysis and Cause-and-Effect Diagram (CED) For Minimizing Rejection of Raw Materials in Lamp Production Process. Management science and engineering. 2011; 5(3): 87-95.

13. Chandna P, Chandra A. Quality Tools to Reduce Crankshaft Forging Defects: An Industrial Case Study. Journal of Industrial and Systems Engineering. 2009; 3(1): 27-37.

14. Perera AA, Navaratne SB. Application of Pareto principle and Fishbone diagram for Waste Management in a Powder Filling Process. International Journal of Scientific and Engineering Research. 2016; 7(11): 181-184

15. Magar VM, Shinde VB. Application of 7 Quality Control (7 QC) Tools for Continuous Improvement of Manufacturing Processes. International Journal of Engineering Research and General Science. 2014;2(4):364-71.

16. Ding SH, Muhammad NA, Zulkurnaini NH, Khaider AN, Kamaruddin S. Production System Improvement by Integration of FMEA with 5-WHYS Analysis. InAdvanced Materials Research. 2013: 748;1203-1207. 
17. Crema M, Verbano C. Guidelines for Overcoming Hospital Managerial Challenges: A Systematic Literature Review. Therapeutics and clinical risk management. 2013; 9:427.

18. Sondalini M. Understanding How to Use The 5-Whys For Root Cause Analysis. Plant, Equipment and Reliability Improvement. 2013;1.

19. Kumbhar KN. Brainstorming Technique: Innovative Quality Management Tool for Library. Current Trends in Library Management. 2018.

20. Sauer BC, Hepler CD. Application of System-Level Root Cause Analysis for Drug Quality and Safety Problems: A Case Study. Research in social and administrative pharmacy. 2013; 9(1):49-59.

21. Yusuf Y, Trisiana A. Metode Braistorming Tertulis: Teknik Curah Pendapat Dengan Memaksimalkan Keterlibatan Semua Peserta Dalam Pengambilan Keputusan. Adi Widya: Jurnal Pengabdian Masyarakat. 2019;3(2):108-16.

22. Amin D. Penerapan Metode Curah Gagasan (Brainstorming) Untuk Meningkatkan Kemampuan Mengemukakan Pendapat Siswa. Jurnal Pendidikan Sejarah. 2016; $5(2): 1-5$.

23. Rana S, Belokar RM. Quality Improvement Using FMEA: A Short Review. International Research Journal of Engineering and Technology. 2017;4(6):263-7.

24. Bhattacharya J, Pharm M, Phil M. Quality Risk Management-Understanding and Control the Risk in Pharmaceutical Manufacturing Industry. International Journal of Pharmaceutical Science Invention. 2015; 4(1):29-41.

25. Hajiagha SH, Hashemi SS, Mohammadi Y, Zavadskas EK. Fuzzy belief Structure Based VIKOR Method: An Application for Ranking Delay Causes of Tehran Metro System by FMEA Criteria. Transport. $2016 ; 31(1): 108-18$.

26. Liu HC, Li P, You JX, Chen YZ. A Novel Approach for FMEA: Combination of Interval 2-Tuple Linguistic Variables and Gray Relational Analysis. Quality and Reliability Engineering International. 2015; 31(5):761-72.

27. Simsekler MC, Kaya GK, Ward JR, Clarkson PJ. Evaluating Inputs of Failure Modes and Effects Analysis in Identifying Patient Safety Risks. International Journal of Health Care Quality Assurance. 2019; 32(1): 191-207.

28. Hekmatpanah M. The Application of Cause and Effect Diagram in The Oil Industry In Iran: The Case Of Four Liter Oil Canning Process of Sepahan Oil Company. African Journal of Business Management. 2011;5(26):10900-7.

29. De Mast J, Lokkerbol J. An Analysis of The Six Sigma DMAIC Method from the Perspective of Problem Solving. International Journal of Production Economics. 2012; 139(2):604-14.

30. Kaushik P. Relevance of Six Sigma Line of Attack in SMEs: A Case Study of a Die Casting Manufacturing Unit. Journal of Engineering \& Technology. 2011; 1(2): 107113.

31. Garza-Reyes JA, Flint A, Kumar V, Antony J, Soriano-Meier H. A DMAIRC Approach to Lead Time Reduction in an Aerospace Engine Assembly Process. Journal of Manufacturing Technology Management. 2014; 25(1): 27-48.

32. Timans W, Ahaus $\mathrm{K}$, van Solingen R, Kumar M, Antony J. Implementation of Continuous Improvement Based on Lean Six Sigma in Small-and Medium-Sized Enterprises. Total Quality Management \& Business Excellence. 2016; 27(3-4): 30924. 
33. Yuniarto H, Akbari A, Masruroh N. Perbaikan pada Fishbone Diagram Sebagai Root Cause Analysis Tool. Jurnal Teknik Industri . 2013; 3(3).

34. Sarkar L. Pareto analysis of the engineering related quality issues of rural electrification projects. International Journal of Engineering Development and Research. 2018; 6(3): 56-64.

35. Card AJ. The problem with ' 5 whys'. BMJ quality and safety. 2016; 26(8): 671-677.

36. Dahooie J, Vanaki AS, Firoozfar HR, Zavadskas EK, Čereška A. An extension of the failure mode and effect analysis with hesitant fuzzy sets to assess the occupational hazards in the construction industry. International journal of environmental research and public health. 2020; 17(4): 1442.

37. Antony J. A Swot analysis on Six Sigma: some perspectives from leading academics and practitioners. International Journal of Productivity and Performance Management. 2012; 61(6): 691-698. 